\title{
Food Security by Promotion of Pulses through KVK Methodology - A Way of Doubling the Farmers Income
}

\author{
C. Padma Veni ${ }^{1^{*}}$, Bandaru Venkata Rajkumar ${ }^{2}$, D. Vijaya Lakshmi ${ }^{3}$, M. Swetha ${ }^{4}$, \\ P. Vijay Kumar ${ }^{5}$, M. Bhavya Manjari ${ }^{6}$ and K. Dattatri ${ }^{7}$ \\ ${ }^{1}$ (Agril. Extension) \& Programme Coordinator, KVK, Rudrur, Telangana, India \\ ${ }^{2}$ (Horticulture), KVK, Rudrur, Telangana, India \\ ${ }^{3}$ (Crop Production), KVK, Rudrur, Telangana, India \\ ${ }^{4}$ (Agril. Extension), KVK, Rudrur, Telangana, India \\ 5 (Plant Protection), KVK, Rudrur, Telangana, India \\ ${ }^{6}$ (Home Science), KVK, Rudrur, Telangana, India \\ ${ }^{7}$ (Agril. Extension), ATARI, Zone-X, Hyderabad, Telangana, India \\ *Corresponding author
}

\section{A B S T R A C T}

Food security tops the Government agenda as production stagnates and prices continue to be high. Pulses on account of their vital role in nutritional security and soil ameliorative properties have been an integral part of sustainable agriculture since ages. Presently, the pulses are grown in 23 million hectares with 13-15 million tonnes of production in the country. National Food Security Mission on pulses, a centrally sponsored scheme is implemented in the country during 2007 with a goal to increase

\section{Keywords}

Food Security, Promotion, KVK Methodology, Farmers income

\section{Article Info}

Accepted:

18 September 2018

Available Online:

10 October 2018 production and productivity in pulse crops by providing farmers the high yielding variety seeds with improved technology as the Hon'ble Prime Minister Shri Narendra Modi ji emphasised in seven points strategy document for doubling the farmer's income by 2022. This paper describes the sequential extension methods adopted in Cluster Front Line demonstration (CFLD) by Krishi Vigyan Kendra, Nizamabad, Telangana State for the promotion of Bengal gram and Green gram under National Food Security Mission (NFSM) during 2012-2018 in 381 demonstration plots in 152.4 ha to enhance the farmers yield and income. The extension methods used to disseminate the scientific production technologies during different crop stages in CFLD resulted in enhancing the farmers average yield and income in Green gram (8.82q/ha) with $16.67 \%$ increase and Bengal gram (15.56q/ha) with $23.30 \%$ increase in comparison to farmers practice. Besides, these CFLDs also expanded the area under pulses in the district as Nizamabad district is dominated by paddy crop. The high yielding varieties of Green gram and Bengal gram helped the farmers in realizing benefits with assured income especially when paddy could not be taken up in the district during severe drought period (2014-15 with rainfall -48.9 \% \& 2015-16 with rainfall $-51.4 \%)$. 


\section{Introduction}

Food security tops the Government agenda as production stagnates and prices continue to be high. Pulses on account of their vital role in nutritional security and soil ameliorative properties have been an integral part of sustainable agriculture since ages. Presently, the Pulses are grown in 23 million hectares with 13-15 million tonnes of production in the country. National Food Security Mission on Pulses, a centrally sponsored scheme is implemented in the country during 2007 with a goal to increase production and productivity in Pulse crops by providing farmers the high yielding variety seeds with improved technology as the Hon'ble Prime Minister Shri Narendra Modi ji emphasised in seven points strategy document for doubling the farmers income by 2022 .

Though a number of improved Pulse varieties and production technologies have been developed over a period of time, the full potential of these varieties and technologies could not be exploited due to lack of availability to the farmers which limited the pulse productivity and cannot be overlooked. Research and extension programmes need to be diverted to produce value additive pulses.

The concept of Front Line Demonstration in cluster mode was put forth under National Food Security Mission on Pulses by scientists of Krishi Vigyan Kendras (KVK) , State Agricultural Universities(SAUs), Indian Council of Agricultural Research Institutes (ICARs) and NGOs which would indirectly contribute to enhance farmers' income by increasing production and productivity and reducing the cost of production with the promotion of improved seed and scientific technology demonstrated on the selected crop and ensuring remunerative price to the produce produced. Over the last few years, with contributing effect, the area and production of pulses in Nizamabad District increased due to inception of Cluster Front Line Demonstration concept at farmers' field as paddy is dominant crop in the district.

In this connection Krishi Vigyan Kendra, Nizamabad conducted Cluster Front Line Demonstrations since six years (6) (2012-13 to 2017-18) using extension methods to demonstrate the scientific technologies sequentially during different stages of crop in Green gram and Bengal gram and realised the benefits.

\section{Krishi Vigyan Kendra Methodology}

As a mandate, Krishi Vigyan Kendra conducts Technology Assessment and Refinement (TAR) on six (6) micro locations of farmers farm ( 0.1 ha each location) called On Farm Testing (OFT) that move to Demonstration three years after proving sucessful called Front Line Demonstration (FLD). These FLDs are conducted in ten (10) locations of farmers farm ( 0.4 ha each location) in close supervision of scientists so as to establish production potentials. Similarly the concept of Cluster Front Line Demonstration s under NFSM (National Demonstrations) is to conduct the demonstrations in cluster mode approach taking into consideration 10 ha as one cluster to create better and visible impact of a technology in a larger scale through wide publicity.

\section{Sequential Extension Methodology and Technology}

For the development of Sequential Extension Methodology and Technology the sources of growth and strategies for improving the farmers income through Pulse crops and their improved varieties, different stages of CFLD before and during implementation including various crop stages, crop technologies with appropriate extension methods, audio visual 
aids / ICT and farmers feedback were identified and incorporated as shown in the Figure No.1.

\section{Before Implementation of CFLD}

The ground work for identifying the following areas before implementation was done

\section{Sources of Growth in Farmers' Income}

Improving productivity

Increasing resource use efficiency

Saving cost of cultivation

Increasing cropping intensity

\section{Strategy for Improving Farmers Income}

Conducting Cluster Front Line

Demonstrations by

Selecting improved variety \& technology

Developing Sequential Extension Methodology and Technology

Pulse crops along with Technologies, Farmers Practice and Extension Gap identified

The pulse crops along with improved varieties and technologies to be demonstrated through CFLD during 6 years 2012-13 to 2017-18 were identified in consultation with Principal Scientist (Pulses) from SAUs \& ICAR and thoroughly reviewing the literature as shown in below given table 1 and 2. Later the literature was developed on both the crops in local language and distributed to the farmers.

Crop stages identified (For example Bengalgram Nandyal Senaga-1 and Dheera)

Pre sowing

Sowing

Early vegetative (15 Days After Sowing)
Vegetative (30-35 Days After Sowing)

Flowering

Pod formation (55-65 Days After Sowing)

Pod development (75-80 Days After Sowing)

90 Days crop duration

Before harvesting (100 Days crop duration)

Harvesting

Selection of Demonstration plots and farmers

Participatory Rural Appraisal Methods like Social and Resource mapping were conducted to identify uplands suitable for the promotion of Pulses

Brain storming and Interactive sessions were conducted and suitable demonstration plots on cluster approach along with interested and ideal farmers based on their active participation were selected.

\section{Size of CFLD plot}

The size of each demonstration plot 0.4 ha was considered for implementation of CFLD.

\section{Number of farmers}

The number of farmers selected equalled the number of demonstration plots.

Every year 10-12 ha. were considered as one cluster and demonstrations were conducted in 10 to $20 \mathrm{ha}$. in one or two clusters in each crop. Soil Samples from the selected demonstration plots were collected in coordination with Department of Agriculture and distributed the Soil Health Cards for soil test based fertilizer management.

\section{During Implementation of CFLD}

A total of 381 Cluster Front Line Demonstrations in 152.4 ha. in 6 years (201213 to 2017-18) were conducted in the KVK 
adopted and non-adopted villages with active participation of farmers to demonstrate the improved technologies of Green gram and Bengalgram in different villages taking Farmers Practice as a Check so as to establish production potentials and expand the area under these crops in the district as a contributing way of doubling the farmers income

Orientation meetings were conducted and the literature was distributed on the crops during Pre-sowing stage involving the selected farmers. Critical inputs along with technologies to be demonstrated at every stage of the crop were delivered using appropriate extension method. Field days were conducted involving Demonstration holding farmers, Neighbouring farmers, Scientists from University and Agricultural Technology Application Research Institute, Officials from Department of Agriculture and local extension functionaries to demonstrate the superiority of the technology of each crop. Crop yields were recorded from the demonstration and check plots at the time of harvest to identify the yield gaps between demo and check plots

The yield data was collected from both the demonstration and check plots by random crop cutting method for comparison.

The technology gap and technological index (Samui et. al., 2000) were calculated by using formula as given below.

Technology gap = Potential yield Demonstration yield

Potential Yield-Demonstration Yield Technology Index= ---------------------- X 100 Potential Yield

Demonstration yield - farmers yield Percent increase yield $=$ Farmers yield

\section{Mechanized harvesting}

Cost reduction with mechanized harvesting in Dheera (NBeG-47) in comparison to Nandyal Shanaga-1(NBeG-3) in one acre was calculated

A model of Sequential Extension Methodology and Technology in accordance with technologies demonstrated developed for CFLD in Bengalgram varieties Nandyal Shanaga-1 (NBeG-3) and Dheera (NBeG-47) during 2017-18 is presented in Figure. No.1.

Table 3 depicts the yields recorded in Green gram under rain fed situation during kharif season varied from 6.10 to $13.62 \mathrm{q} /$ ha with an average of $8.82 \mathrm{q} / \mathrm{ha}$ in CFLD plots which were more than check wherein, the yields varied from 5.34 to $12.32 \mathrm{q}$ per ha with an average of $7.61 \mathrm{q}$ per ha. The green gram crop during 2017-18 could not be harvested due to uneven distribution of rainfall $(73.4 \mathrm{~mm})$ during the month of September, 2017 coinciding the harvest period which damaged the crop completely. The results indicated that the Cluster frontline demonstrations shown good impact on the farming community of Nizamabad district as they got motivated by the new agricultural technologies disseminated through CFLD in Greengram. The variation in overall yield of Green gram from 2012-13 to 2016-17 was due to fluctuations in ground water table and weather conditions in Nizamabad district. The increase in yield over check ranged from 10.45 per cent (in 2014-15) to 21.14 percent (in 2016-17) with an average of 16.67 per cent.

Table 4 depicts the yields recorded in Bengal gram during rabi seasons varied from 8.13 to $21.18 \mathrm{q} / \mathrm{ha}$ with an average of $15.56 \mathrm{q} / \mathrm{ha}$ in CFLD plots which were more than check wherein, the yields varied from 6.25 to 18.75 q per ha with an average of $12.62 \mathrm{q} / \mathrm{ha}$. The increase in yields over check varied from 7.10 
per cent (in 2012-13) to 47.28 percent (in 2014-15) with an average of 23.30 per cent. The variation in overall yields of Bengal gram from 2012-13 to 2017-18 was due to weather conditions prevailed where this crop grows under residual moisture and atmospheric dew.

As a contributing way for Food and Nutritional Security, the Sequential Extension Methodology and Technology played a key role in Improving the productivity, Resource use efficiency, Saving in cost of production and Increasing cropping intensity in Greengram and Bengalgram crops. Variation in yields in Greengram and Bengalgram over the years as shown in the Table. $3 \& 4$ was due to influence of weather conditions during different crop stages. September 2016 excess rains (295.9 \%), turned Greengram (Madira Pesara) as Green Manuring as the crop on some demonstration plots got completely submerged. KVK scientists intervened at this point in fertilizer management in Rabi Paddy to reduce the dose of nitrogen fertilizers and facilitated the farmers in reducing the cost of cultivation on which a Case Study was documented. Similarly uneven distribution of rainfall $73.4 \mathrm{~mm}$ during September 2017 coinciding with harvesting period of Greengram (Yadadri) completely damaged the crop. Apart from mere technology dissemination with appropriate methodology, the real education provided at every stage of the crop enabled the farmer to understand and adopt technologies and reap good yields realising the nutritional benefits of pulses. The varietal replacement with high yielding, pest and disease resistant characters like Yellow Mosaic Virus in Greengram varieties Madira Pesara and Yadadri (short duration - 60-65 days) and Wilt resistant and Bold seeded Bengal gram Varieties Nandyal Shanaga-1 (NBeG-3) and Dheera (NBeG-47) helped the farmers to realize the benefits of getting high yields in Green gram (8.82q/ha) with $16.67 \%$ increase \& Bengal gram (15.56q/ha) with $23.30 \%$ increase in comparison to Farmers Practice and motivated them in spreading the technology in the district.

Proper Audio Visual Aid and ICT use, obtaining farmer's feedback at every crop stage and video films covering crucial crop management aspects imparted knowledge to the farmers for timely management of pests and diseases. Capturing and spreading the farmer innovation like growing crop on raised beds with high yields @ 30q/ha motivated the fellow farmers to adopt and practice the same for realizing the benefits. The Field Days conducted at economic part development stage (pod development) with the involvement of demonstration holding farmers, neighbouring farmers, Scientists from SAU and ICARATARI, Agriculture department officials, local extension functionaries with wide publicity using print and electronic media demonstrated the superiority of technology over farmers practice in both crops and enabled the farmers to spread the technology of the crops in the district. The resource poor and distressed farmers especially, realized the benefits with assured income during severe drought period (2014-15 with rainfall $-48.9 \%$ \& 2015-16 with rainfall $-51.4 \%$ ) where paddy could not be taken up in the district.

Doubling the farmers income cannot be focused per se. Front Line Demonstration's conducted in cluster mode (area approach) which is farm centric under NFSM aimed at enhancing production and productivity for food security that give the farmers a sense of income security over a period of time. Income security of farmers is a broader subject that demands both farm centric and farmer centric approaches which requires generating income from integrated agricultural and nonagricultural enterprises over a period of time from the base year. 
Table.1 Technologies Identified, Farmers Practices and Extension Gap under CFLD on Green gram during Kharif season

\begin{tabular}{|l|}
\hline $\begin{array}{l}\text { Particulars of } \\
\text { Greengram }\end{array}$ \\
\hline Variety \\
\hline Seed rate \\
\hline Seed treatment \\
\hline Fertilizer dose \\
\hline Weed \\
management \\
\hline Plant protection \\
\hline
\end{tabular}

Technological intervention in CFLD

Improved varieties LGG-460, Eakasila (WGG-37), Yadadri (WGG42) and Madira Pesara (MGG-347)

$15-20 \mathrm{~kg} / \mathrm{ha}$

Carbendazim@3.0g/kg. seed, Rhizobium@500 g/ha seed

$25 \mathrm{~kg}$ Urea \& $300 \mathrm{~kg}$ SSP

Pendimithalin@2.5 L/ha and one hand weeding@30-45 DAS, Spraying Carbendizum + Mancozeb $2.5 \mathrm{~g} / \mathrm{l}$. for control of powdery meldew (control of insects with 2 sprays of insecticide at vegetative stage and pod development stage)

Need based and timely spraying of above chemicals

\begin{tabular}{l|l}
\hline Farmers practices & Extension Gap \\
\hline Local/own seed & Full gap \\
\hline $\begin{array}{l}20-25 \mathrm{~kg} / \mathrm{ha} \\
\text { No seed treatment }\end{array}$ & Partial gap (High seed rate) \\
\hline $\begin{array}{l}\text { Excess use of fertilizer } \\
\text { Pendimithalin @ 2.5 } \\
\text { L/ha }\end{array}$ & Partial gap \\
\hline $\begin{array}{l}\text { Improper measures \& } \\
\text { biopesticides spraying }\end{array}$ & Full gap \\
\hline
\end{tabular}

Table.2 Technologies Identified, Farmers Practices and Extension Gap under CFLD on Bengal gram Rabi season

\begin{tabular}{|c|c|c|c|}
\hline $\begin{array}{l}\text { Particulars of } \\
\text { Bengal gram }\end{array}$ & $\begin{array}{l}\text { Technological intervention in } \\
\text { CFLD }\end{array}$ & Existing practices & Extension Gap \\
\hline Variety & $\begin{array}{l}\text { Improved varieties JG-11, } \\
\text { Nandyal Shanaga-1 (NBeG-3) } \\
\text { and Dheera (NBeG-47) }\end{array}$ & Local/own seed & Full gap \\
\hline Seed rate & $62.5 \mathrm{~kg} / \mathrm{ha}$ & $75 \mathrm{~kg} / \mathrm{ha}$ & Partial gap (High seed rate) \\
\hline Seed treatment & $\begin{array}{l}\text { Trichoderma viridae @6g/kg } \\
\text { seed and Corboxin 75\% WP } \\
\text { @1g/kg seed. Rhizobium @ } 500 \\
\text { g/ha seed }\end{array}$ & No seed treatment & Full gap \\
\hline Fertilizer dose/ha & $25 \mathrm{~kg}$ Urea \& $300 \mathrm{~kg}$ SSP & No use of fertilizer & Full gap \\
\hline Weed management & $\begin{array}{l}\text { Pendimithalin@2.5 L/ha and } \\
\text { one hand weeding @ 30-45 DAS }\end{array}$ & $\begin{array}{l}\text { Pendimithalin@ } 2.5 \\
\text { L/ha }\end{array}$ & Partial gap \\
\hline Plant protection & $\begin{array}{l}\text { Installation of bird perches } 30 \text { - } \\
40 / \text { ha. } \\
\text { Spraying of insecticide } \\
\text { Quinalphos @ } 2 \mathrm{ml} / \text { lit. at pod } \\
\text { development stage to control pod } \\
\text { borers. } \\
\text { Need based timely spraying }\end{array}$ & $\begin{array}{l}\text { Improper measures \& } \\
\text { bios spraying }\end{array}$ & Full gap \\
\hline Harvesting & $\begin{array}{l}\text { Mechanized harvesting in Dheera } \\
\text { (NBeG-47) }\end{array}$ & No mechanization & Full Gap \\
\hline
\end{tabular}


Table.3 Performance of Green gram under Cluster Frontline Demonstrations and Farmers Practice (check) during Kharif season from 2012-13 to 2017-18 (Pooled data)

\begin{tabular}{|c|c|c|c|c|c|c|c|c|c|c|c|}
\hline \multirow[t]{2}{*}{ Year } & \multirow[t]{2}{*}{ Demo Variety } & \multirow{2}{*}{$\begin{array}{l}\text { No. of } \\
\text { Demos }\end{array}$} & \multirow{2}{*}{$\begin{array}{c}\text { Area } \\
\text { (ha) }\end{array}$} & \multicolumn{2}{|c|}{ Yield (q/ha) } & \multirow{2}{*}{$\begin{array}{l}\% \text { increase } \\
\text { over check }\end{array}$} & \multicolumn{2}{|c|}{ B:C ratio } & \multirow{2}{*}{$\begin{array}{l}\text { Potential } \\
\text { yield } \\
\text { (q/ha) }\end{array}$} & \multirow{2}{*}{$\begin{array}{l}\text { Technology } \\
\text { gap } \\
\text { (q/ha) }\end{array}$} & \multirow{2}{*}{$\begin{array}{c}\text { Technology } \\
\text { index } \\
(\%)\end{array}$} \\
\hline & & & & Demo & Check & & Demo & Check & & & \\
\hline $2012-13$ & LGG-460 & 30 & 12 & 6.95 & 5.82 & 19.42 & $2.19: 1$ & 1.99:1 & 13.75 & 6.80 & 49.45 \\
\hline 2013-14 & Eakasila & 30 & 12 & 6.10 & 5.34 & 14.23 & $2.17: 1$ & $1.88: 1$ & 13.75 & 7.65 & 55.64 \\
\hline 2014-15 & Eakasila & 30 & 12 & 13.62 & 12.32 & 10.45 & $2.14: 1$ & $1.88: 1$ & 13.75 & 0.13 & 0.95 \\
\hline $2015-16$ & Yadadri (FLD) & 5 & 2 & 6.85 & 5.80 & 18.10 & $2.39: 1$ & $2.03: 1$ & 12.5 & 5.65 & 45.20 \\
\hline 2016-17 & Madira Pesara & 21 & 8.4 & 10.60 & 8.75 & 21.14 & $2.24: 1$ & $2.75: 1$ & 12.5 & 1.90 & 15.20 \\
\hline 2017-18 & Yadadri & 50 & 20 & \multicolumn{8}{|c|}{ Crop failed due to heavy rainfall } \\
\hline Average & & - & - & 8.82 & 7.61 & 16.67 & - & - & - & - & - \\
\hline Total & & 166 & 66.4 & - & - & - & - & - & - & - & - \\
\hline
\end{tabular}

Table.4 Performance of Bengal gram under Cluster Frontline Demonstration and Farmers Practice (check) during Rabi season from 2012-13 to 2016-17 (Pooled data)

\begin{tabular}{|c|c|c|c|c|c|c|c|c|c|c|c|}
\hline \multirow[t]{2}{*}{ Year } & \multirow[t]{2}{*}{ Demo Variety } & \multirow{2}{*}{$\begin{array}{l}\text { No. of } \\
\text { Demos }\end{array}$} & \multirow{2}{*}{$\begin{array}{l}\text { Area } \\
\text { (ha) }\end{array}$} & \multicolumn{2}{|c|}{ Yield (q/ha) } & \multirow{2}{*}{$\begin{array}{l}\% \text { increase } \\
\text { over check }\end{array}$} & \multicolumn{2}{|c|}{ B:C ratio } & \multirow{2}{*}{$\begin{array}{c}\text { Potential } \\
\text { yield } \\
\text { (q/ha) }\end{array}$} & \multirow{2}{*}{$\begin{array}{c}\text { Technology } \\
\text { gap }\end{array}$} & \multirow{2}{*}{$\begin{array}{l}\text { Technology } \\
\text { index }(\%)\end{array}$} \\
\hline & & & & Demo & Check & & Demo & Check & & & \\
\hline $2012-13$ & JG-11 & 30 & 12 & 13.87 & 12.95 & 7.10 & $2.35: 1$ & $2.32: 1$ & 22.5 & 8.63 & 38.30 \\
\hline 2013-14 & JG-11 & 30 & 12 & 21.18 & 18.75 & 12.9 & $2.42: 1$ & $2.32: 1$ & 22.5 & 1.32 & 5.86 \\
\hline 2014-15 & JG-11 & 30 & 12 & 13.30 & 9.03 & 47.28 & $2.36: 1$ & 2.01:1 & 22.5 & 9.20 & 40.80 \\
\hline 2015-16 & JG-11 & 25 & 10 & 8.13 & 6.25 & 30.08 & $2.22: 1$ & $2.47: 1$ & 22.5 & 14.37 & 63.87 \\
\hline 2016-17 & Nandyal Shanaga -3 & 50 & 20 & 18.78 & 13.75 & 36.58 & $2.45: 1$ & $2.20: 1$ & 25.00 & 6.22 & 24.88 \\
\hline 2017-18 & $\begin{array}{c}\text { Nandyal Shanaga-1 } \\
\text { \& Dheera }\end{array}$ & 50 & 20 & 18.13 & 15 & 20.86 & 3.26 & 2.45 & 25.00 & 6.87 & 27.48 \\
\hline Average & - & - & - & 15.56 & 12.62 & 23.30 & - & - & - & - & - \\
\hline Total & - & 215 & 86 & - & - & - & - & - & - & - & - \\
\hline
\end{tabular}


Sequential Extension Methodology and Technology in Bengal Gram NBeG-3 \&NBeG-47

CFLD during Rabi 2017-18 Developed by KVK, Nizamabad

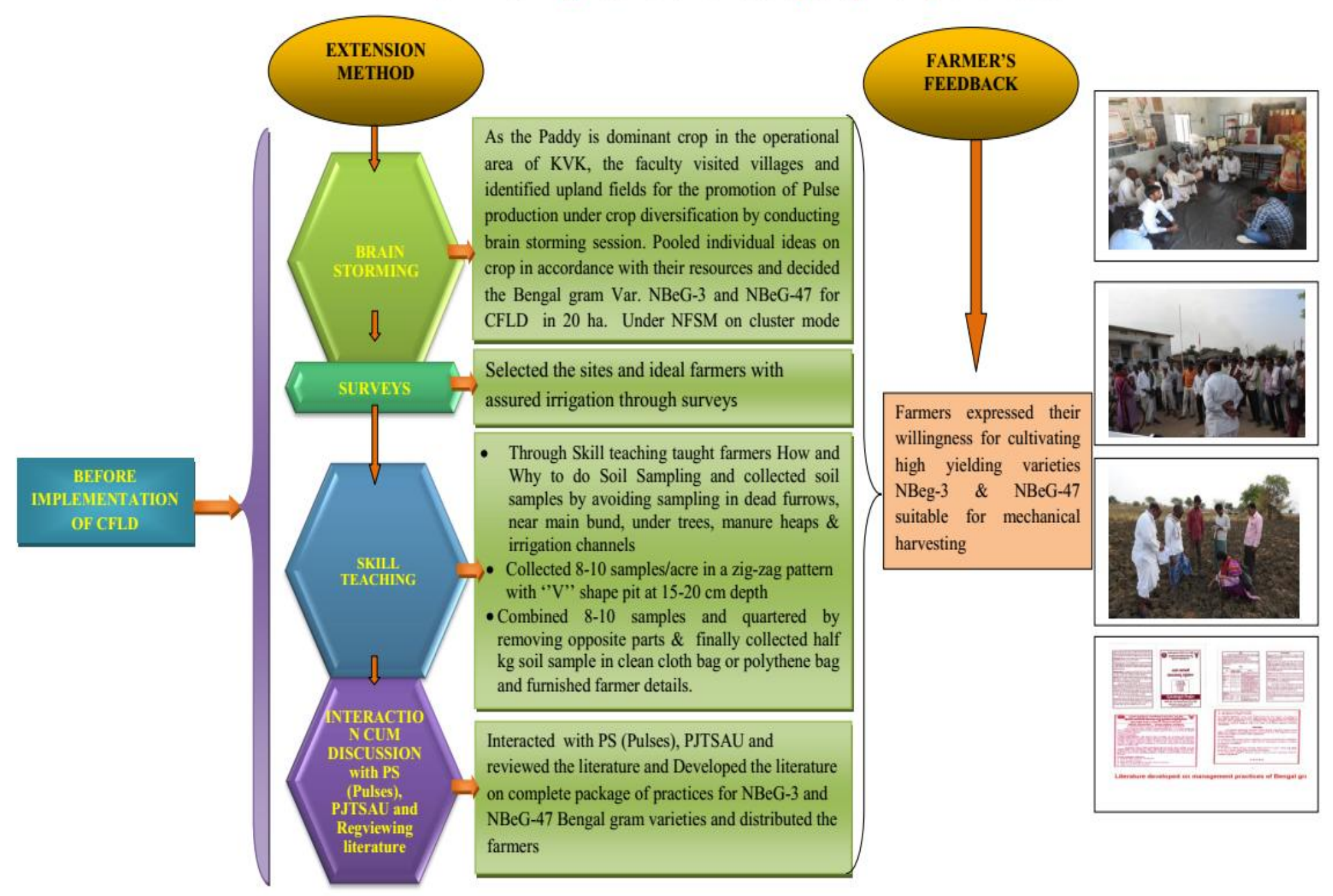




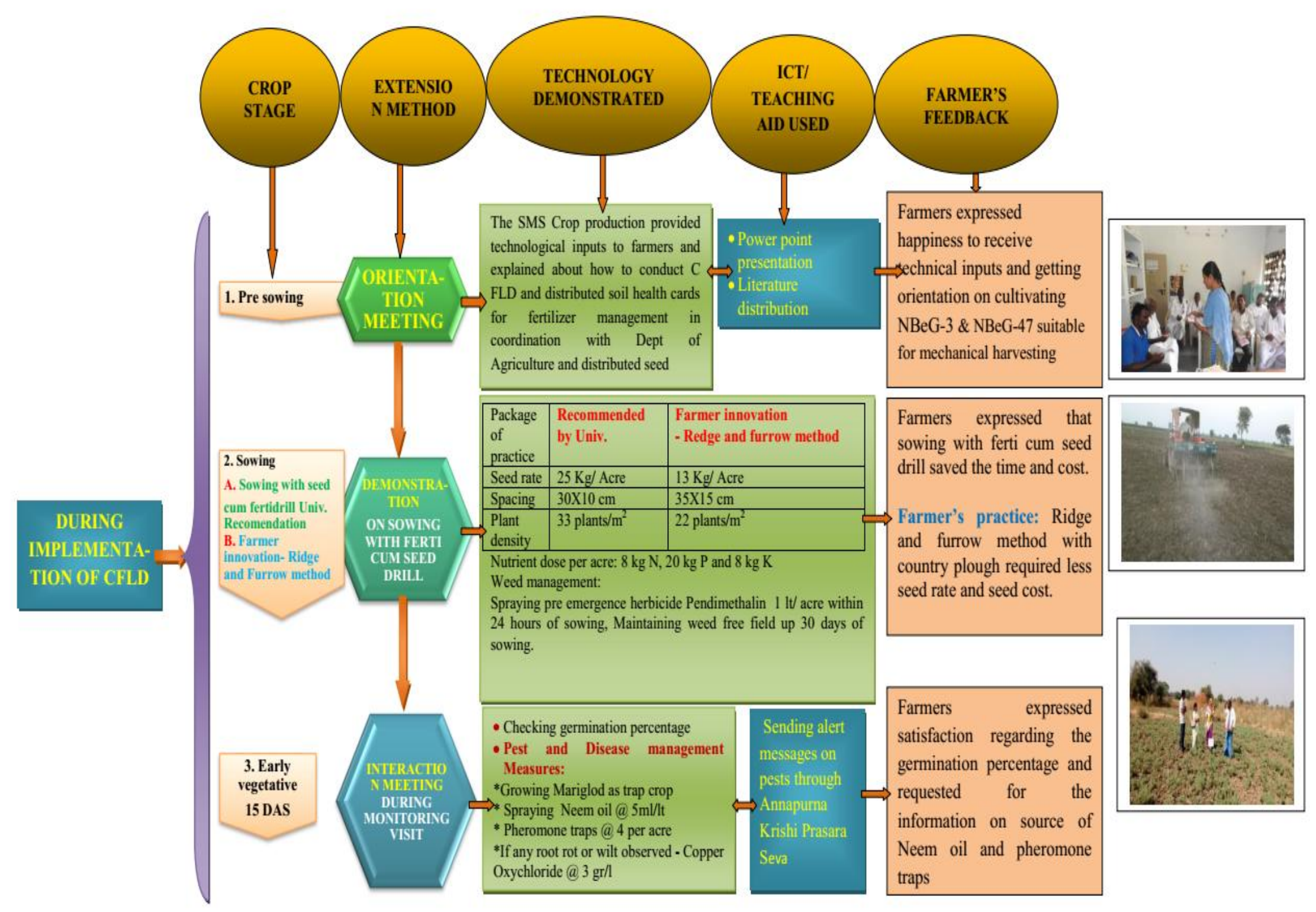




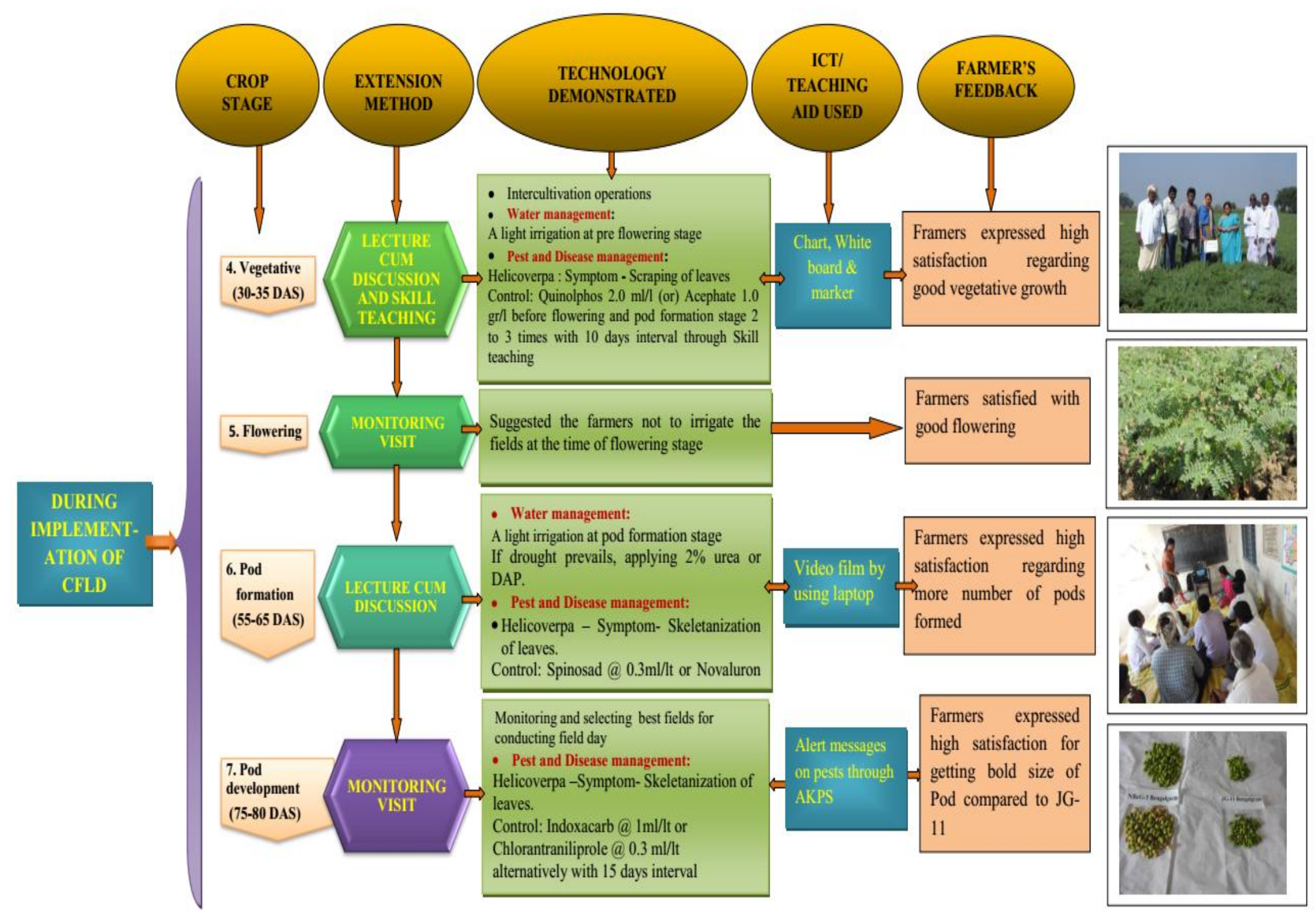




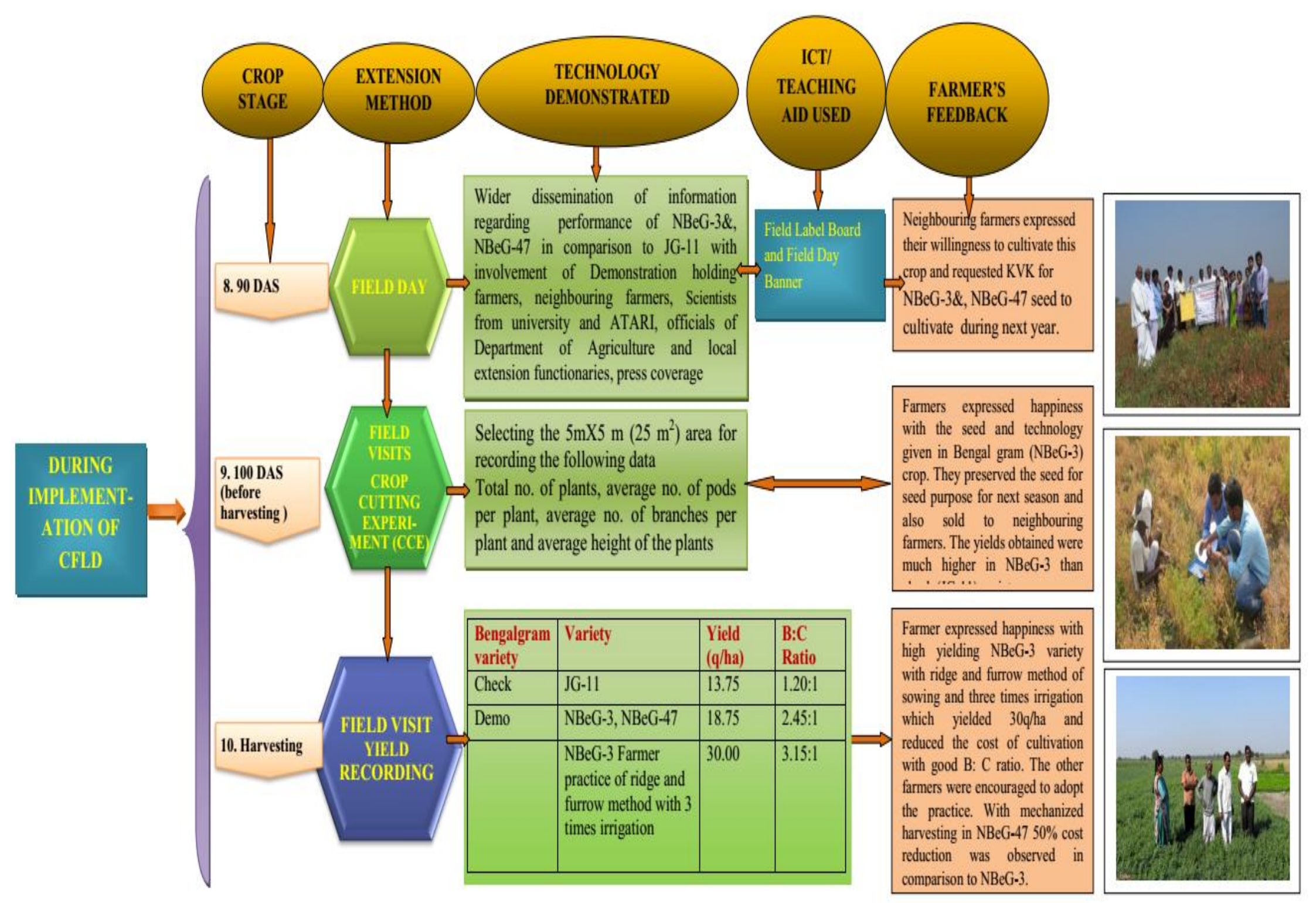




\section{Extension methods selected}

1. Participatory Rural Appraisal Methods (PRA)

2. Brain storming sessions

3. Surveys

4. Skill Teaching

5. Interaction with Principal Scientist (Pulses) cum literature review

Before implementation of CFLD

6. Orientation meetings

7. Demonstrations

8. Interaction meeting

9. Lecture cum Discussion

10. Monitoring visits

11. Skill Teachings

12. Field days

13. Field visits

The effort of KVK, Nizamabad in conducting CFLD's on Greengram and Bengalgram with appropriate strategy for improving farmers income by following Sequential Extension Methodology and Technology enabled the farmers to improve the productivity, resource use efficiency, saving cost of cultivation (good B.C ratio) and increasing cropping intensity which indirectly might have contributed in enhancing their income.

Implementation of any extension activity as a contributing way of doubling the farmer's income over a period of set time from the base year demands adequate and timely fund flow mechanism. As saying goes 'Research without Extension is only a hobby and Extension without Research is folly,' adopting well designed Sequential Extension
Methodology and Technology so as to reach Research output to the farmers through Extension is the need of hour. Successful implementation of extension activity like Cluster Front Line Demonstrations through $K V K s$ definitely contribute to envision the dream of Hon'ble Prime Minster Sri Narendra Modi ji come true as emphasized in 7 points strategy document for Doubling the Farmers Income by 2022.

\section{References}

Samui, S. K., Maitra, S., Roy, D. K., Mondal. A. K. and Saha, D. (2000). Evaluation on front line demonstration on groundnut (Arachis hypogea L.). Journal of Indian Society Coastal Agricultural Research. 18: 180-183.

\section{How to cite this article:}

Padma Veni C., Bandaru Venkata Rajkumar, D. Vijaya Lakshmi, M. Swetha, P. Vijay Kumar, M. Bhavya Manjari and Dattatri, K. 2018. Food Security by Promotion of Pulses through KVK Methodology - A Way of Doubling the Farmers Income. Int.J.Curr.Microbiol.App.Sci. 7(10): 2585-2596. doi: https://doi.org/10.20546/ijcmas.2018.710.300 